\title{
Effect of freezing on rabbit cultured chondrocytes
}

[Efeitos do congelamento sobre condrócitos cultivados de coelhos]

\author{
R.R. Filgueiras ${ }^{1}$, R.J. Del Carlo ${ }^{1}$, N.P. Alves ${ }^{2}$, M.I.V. Viloria ${ }^{1}$, C.M. McManus ${ }^{3}$, M.B. Castro ${ }^{3}$, \\ F.P.F. Filgueiras ${ }^{3}$, B.S. Monteiro ${ }^{1}$, A.C. Paula ${ }^{4}$, A. Farias ${ }^{5}$ \\ Departamento de Medicina Veterinária - UFV \\ 36570-000 - Viçosa, MG \\ ${ }^{2}$ Tecnogene Laboratório de Diagnóstico Molecular Ltda. - Brasília, DF \\ ${ }^{3}$ Faculdade de Agronomia e Medicina Veterinária - UnB - Brasília, DF \\ ${ }^{4}$ Canil da Polícia do Exército - Brasília, DF \\ ${ }^{5}$ Hospital Veterinário UPIS - Brasília, DF
}

\begin{abstract}
This work evaluated the effect of freezing on chondrocytes maintained in culture, aiming the establishment of a cell bank for future application as heterologous implant. Chondrocytes extracted from joint cartilage of nine healthy New Zealand White rabbits were cultivated and frozen with the cryoprotector 5\% dimethylsulfoxide for six months. Phenotypic and scanning electron microscopy analyses were carried out to identify morphological and functional differences between fresh and thawed cells. After enzymatic digestion, a total of $4.8 \times 10^{5}$ cells per rabbit were obtained. Fresh chondrocytes showed a high mitotic rate and abundant matrix was present up to 60 days of culture. Loss of phenotypic stability was notable in the thawed chondrocytes, with a low labeling of proteoglycans and weak immunostaining of type II collagen. The present study showed important loss of chondrocyte viability under the freezing conditions. For future in vivo studies of heterologous implant, these results suggests that a high number of cells should be implanted in the host site in order to achieve an adequate number of viable cells. Furthermore, the chondrocytes should be implanted after two weeks of culture, when the highest viability rate is found.
\end{abstract}

Keywords: rabbit, cell freezing, cell therapy, joint cartilage, type II collagen

\section{RESUMO}

Avaliaram-se os efeitos do congelamento sobre condrócitos mantidos em cultura, com o objetivo de se estabelecer um banco celular para futura aplicação como implante heterólogo. Condrócitos extraídos da cartilagem articular de nove coelhos saudáveis, da raça Nova Zelândia Branca, foram cultivados $e$ submetidos ao congelamento, com o citoprotetor sulfóxido de dimetila a 5\%, por um período de seis meses. Análises fenotípicas e de microscopia eletrônica de varredura foram realizadas com o objetivo de identificar diferenças morfológicas e funcionais entre as células frescas e as descongeladas. Após a digestão enzimática, foram obtidas $4,8 \times 10^{5}$ células por coelho. Os condrócitos frescos apresentaram elevada taxa mitótica e abundante presença de matriz até os 60 dias de cultura. Nas culturas dos condrócitos descongelados, a perda de estabilidade fenotípica foi marcante, o que foi demonstrado pela baixa intensidade da coloração dos proteoglicanos e pela fraca imunomarcação do colágeno tipo II. Sob as condições de congelamento utilizadas, houve importante perda de viabilidade condrocítica. Para futuros estudos in vivo de implante heterólogo, estes resultados sugerem que o elevado número de células deve ser implantado no sítio hospedeiro, com o objetivo de se obter maior quantidade de células viáveis, e que os condrócitos deverão ser implantados com duas semanas de cultivo, período em que apresentam melhor taxa de viabilidade.

Palavras-chave: coelho, congelamento celular, terapia celular, cartilagem articular, colágeno tipo II

Recebido em 7 de maio de 2010

Aceito em 28 de dezembro de 2010

E-mail: richardfilgueiras@gmail.com 


\section{INTRODUCTION}

Cartilaginous tissue of the articular surface is not vascularized and its nutrition is carried out by diffusion of substances found in synovial fluid, reason why articular cartilage lesions are difficult to heal (Lombelo et al., 2003). Several surgical and clinical treatments have been proposed over the years to repair articular lesions, including surgical excision of damaged tissue (Denoncourt et al., 1986), electrotherapy (Sousa et al., 2001), use of nutraceuticals (Henrotin et al., 2005), and mosaycplasty (Huntley et al., 2005). Nevertheless, all these procedures have resulted in a tissue with fibrocartilaginous repair, which does not have the same biomechanical properties of hyaline articular cartilage. In this context, cellular therapy may be used as an alternative to obtain the best morphophysiological repair result.

The clinical use of cultivated autologous chondrocyte implants began in 1987 (Jones and Peterson, 2006). At present, this method is used in human patients who are carriers of osteoarthritis with the inconvenience of an operatory procedure for collection and other for cell implantation (Peterson et al., 2003; Pruksakorn et al., 2009).

The use of heterologous chondrocytes means that the patient is submitted to a single implantation surgery, with a low or inexistent immune response (Stevenson, 1987). Hidaka et al. (2003) informed that chondrocytes are immunoprivileged cells and showed, in horse articular cartilage, that inflammatory cells were not observed at eight months after implantation.

Heterologous chondrocytes may be cryopreserved in liquid nitrogen and maintained as a cell bank for an indeterminate time frame. However, during freezing, there is a possibility of intracellular crystals formation, and they may break the cell membrane. The addition of a cryoprotector to the culture medium, such as dimethylsulfoxide (DMSO) and serum proteins from fetal bovine serum (FBS), protect the cells from thermal and osmotic shock (Almqvist et al., 2001).

The objective of this study was to evaluate the effects of freezing on cultivated articular chondrocytes aiming at establishing a protocol to create a bank of heterologous chondrocytes for future in vivo implant.

\section{MATERIAL AND METHODS}

The experiment was approved by the Ethics Committee of the Universidade Federal de Viçosa.

Cartilage was obtained by biopsy of the left stifle joint of nine healthy one-year-old males, New Zealand White rabbits, after intravenous anesthesia with propofol 10\% (Propovan, Cristalia Chemical Products), using a dose of $10 \mathrm{mg} / \mathrm{kg}$, followed by an epidural anesthesia with ropivacaine $0.75 \%$ (Ropi, Cristalia Chemical Products), at a dose of $2.25 \mathrm{mg} / \mathrm{kg}$. After aseptic preparation, the left stifle joint was exposed and cartilage fragments were removed from the lateral and medial femoral condyles using a number 15 scalpel blade. The fragments were collected in a sterile metallic plate and then cut with a number 15 scalpel blade to approximately $1 \mathrm{~mm}^{2}$. Eight of these small fragments, free from soft tissue and subchondral bone, were selected from each rabbit. After collection, the articular capsule, subcutaneous tissue, and skin were sutured and all rabbits received a $30 \mathrm{mg} / \mathrm{kg}$ intramuscular injection of 10\% cephazoline (Cephazoline 1g, Bristol Myers Squibb) and $2.0 \mathrm{mg} / \mathrm{kg} \quad 10 \%$ ketoprofene (Ketofen, Merial Animal Health), subcutaneously, for three days, every 24 hours.

The technique used for cell culture was adapted from Freshney (2005). Cartilage fragments were deposited in sterile plastic tubes containing $10 \mathrm{~mL}$ of Ham's F12 culture medium adding $1 \%$ antibiotic-antimycotic (penicillin G, streptomycin, and amphotericin B - GibcoInvitrogen). The tubes were identified for each rabbit and taken to the laboratory in a refrigerated recipient.

The cartilage samples were transferred to sterile beaker and submitted to enzymatic digestion for 25 minutes, with $0.05 \%$ trypsin (GibcoInvitrogen) diluted in $10 \mathrm{~mL}$ Ham's F12. After trypsin removal, another digestion was carried out for 30 minutes, with $0.3 \%$ collagenase type I (Gibco-Invitrogen) in 10mL Ham's F12. All procedures were carried out in a magnetic stirrer, at room temperature and under sterile conditions. 
The collagenase solution was removed and fragments transferred to $25 \mathrm{~cm}^{2}$ culture flasks containing $0.06 \%$ collagenase in $10 \mathrm{~mL}$ Ham's F12 with 10\% FBS (Cultilab, Medium for Cellular Culture). The material was placed in an incubator at $37^{\circ} \mathrm{C}$, with $5 \% \mathrm{CO}_{2}$, for 15 hours. The suspension was then transferred to a $50 \mathrm{~mL}$ centrifuge tube and agitated in a vortex for a few seconds. It was then filtered through a $70-\mu \mathrm{m}$ nylon filter (BD-Falcon), and the suspended chondrocytes were counted in a hemocytometer. After counting, the chondrocytes were transferred to $25 \mathrm{~cm}^{2}$ culture flasks containing $5 \mathrm{~mL}$ of complete growth medium composed of Dulbeco Modified Eagle Medium dmem)/Ham's F12 (1:1, v/v), 1\% antibiotic-antimycotic solution, and $10 \%$ FBS.

Each flask received $4.8 \times 10^{5}$ chondrocytes. The flasks were incubated at $37^{\circ} \mathrm{C}$, with $5 \%$ of $\mathrm{CO}_{2}$, until $75 \%$ confluence was reached. Afterward, the chondrocytes were removed from the flask

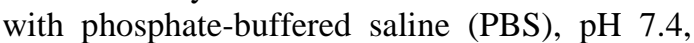
containing $\quad 0.1 \%$ trypsin and $0.02 \%$ ethylenediaminetetraacetic acid (EDTA), and washed for five minutes in DMEM medium containing $10 \%$ FBS to neutralize the trypsin. The chondrocytes were centrifuged at $400 \mathrm{~g}$ for ten minutes in a refrigerated centrifuge and underwent a new subculture. After 10 subcultures, the chondrocytes were resuspended and counted in a hemocytometer. Half of the cell suspension $(2.5 \mathrm{~mL})$ of each sample was frozen. The other half of cell suspension was cultivated again and, every three days, subcultures were carried out until 60 days.

After counting, the chondrocytes were resuspended in a $15 \mathrm{~mL}$ centrifuge tube containing a cooled medium composed of DMEM and 10\% FBS. To this suspension, DMSO (Dimesol, Marcolab Pharmaceutical Products) was slowly added to 5\%. This was then transferred to labeled cryo-tubes at a concentration of $2.4 \times 10^{6}$ cells $/ \mathrm{mL}$. The cryotubes were kept in a freezer at $-20^{\circ} \mathrm{C}$, for $45 \mathrm{~min}$, and later stored in liquid nitrogen for six months.

After six months, the cryo-tubes were taken from the liquid nitrogen and quickly placed in a water bath at $37^{\circ} \mathrm{C}$ to thaw the cellular suspension. Next, the chondrocytes were resuspended in complete growth medium, as described before, and counted in a hemocytometer; cell viability was then determined. The chondrocytes were distributed into nine $75-\mathrm{cm}^{2}$ flasks and incubated at $37^{\circ} \mathrm{C}$, with $5 \% \mathrm{CO}_{2}$, for 11 days.

Both fresh and frozen chondrocytes were observed every three days during the 60 days of cultivation with an inverted phase contrast microscope (model CK2, Olympus), to evaluate the behavior of the chondrocytes in relation to adherence to the plastic flask surface and the presence of matrix in culture.

Cellular viability was determined by the Trypan Blue dye exclusion test (Cambrex Corporation) and cells were counted in a hemocytometer. Fresh cell viability was determined at three different times: immediately after enzymatic digestion and after 15 and 60 days of culture. For thawed cells, viability was determined immediately after thawing and after 15 and 60 days of culture after thawing.

The fresh chondrocytes were analyzed under an electron microscope after 15 and 60 days of culture and the frozen ones after 15 and 60 days of culture after thawing.

A 5mm-diameter sterile glass cover slip was placed in the bottom of each well of six-well culture plates containing complete growth medium. Then, $2 \times 10^{4}$ cells were seeded to each well. The plates were placed in an incubator at $37^{\circ} \mathrm{C}$, with $5 \% \mathrm{CO}_{2}$ for 18 hours, so that the chondrocytes would stick to the cover slips. After this period, the cover slips were washed

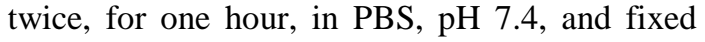
with 5\% glutaraldehyde diluted in PBS, $\mathrm{pH} 7.4$ $(1: 1, v / v)$, during one hour at room temperature. The chondrocytes were then post-fixed for four

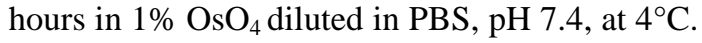
Dehydration with ethanol and critical point drying was carried out. The chondrocytes were metalized with thermal deposition of gold/palladium. A high resolution microscope (LEO 1430VP, Carl Zeiss Inc) was used to observe the morphology of the chondrocytes and matrix formation.

Alcian Blue labeling was used to show functional differentiation of the chondrocytes, which stains sulphate proteoglycans in the extracellular matrix. After 15 days of culture, the fresh chondrocytes of one flask and the thawed chondrocytes of another were fixed in $4 \%$ 
paraformaldehyde for 15 minutes at room temperature and labeled with 1\% Alcian Blue diluted in $0.1 \mathrm{~N} \mathrm{HCl}$. After labeling, the chondrocytes were observed in an inverted phase contrast microscope.

Type II collagen, synthesized by active chondrocytes, was used as a marker of cellular activity. After 15 days of culture, the fresh and frozen choncrocytes were transferred to six-well culture plates containing complete growth medium and a 5mm-glass cover slip in the bottom of each well. In each well, $2 \times 10^{4}$ cells were seeded. After 24 hours of incubation at $37^{\circ} \mathrm{C}$, with $5 \% \mathrm{CO}_{2}$, the cover slips with the stuck chondrocytes were washed twice with PBS, pH 7.4; fixed at room temperature in $4 \%$ paraformaldehyde for ten minutes; and incubated for 12 hours at $4^{\circ} \mathrm{C}$, with a primary antibody (mouse monoclonal anti-Type II collagen antibody - Lab-Vision). After three washes in PBS, pH 7.4, the chondrocytes were incubated at room temperature for two hours with a secondary antibody (sheep anti-mouse IgG conjugated with fluorescent isotiocianate - Cappel Organon Teknika Corp), diluted in PBS, pH 7.4, at 1/100. After various washings in PBS, $\mathrm{pH} 7.4$, the cover slips were mounted in a fluorescent medium
(Dako Corp) and observed under a fluorescence microscope (Carl Zeiss Inc) equipped with a mercury lamp.

The animals were randomly allocated to treatments. Statistical analysis was carried out using SAS/(Enterprise Guide v.4) and significance level of $5 \%$ was considered. When necessary, data were transformed by arcsine or square root. The response to freezing was analyzed using the F test of Proc GLM. When a significant interaction of treatment (frozen or fresh) versus time had occurred, the data were analyzed within each treatment. Linear and quadratic regressions were fitted for culture time using Proc REG (Regression) and results are shown graphically.

\section{RESULTS}

Approximately $4.8 \times 10^{5}$ chondrocytes were found per rabbit, which were multiplied and reached $75 \%$ confluence from three to four days. The chondrocytes maintained their rounded shape and were found stuck to the flask surface one hour after enzymatic digestion, showing spreading and cellular adhesion after three days of culture (Fig. $1 \mathrm{~A}$ and B).
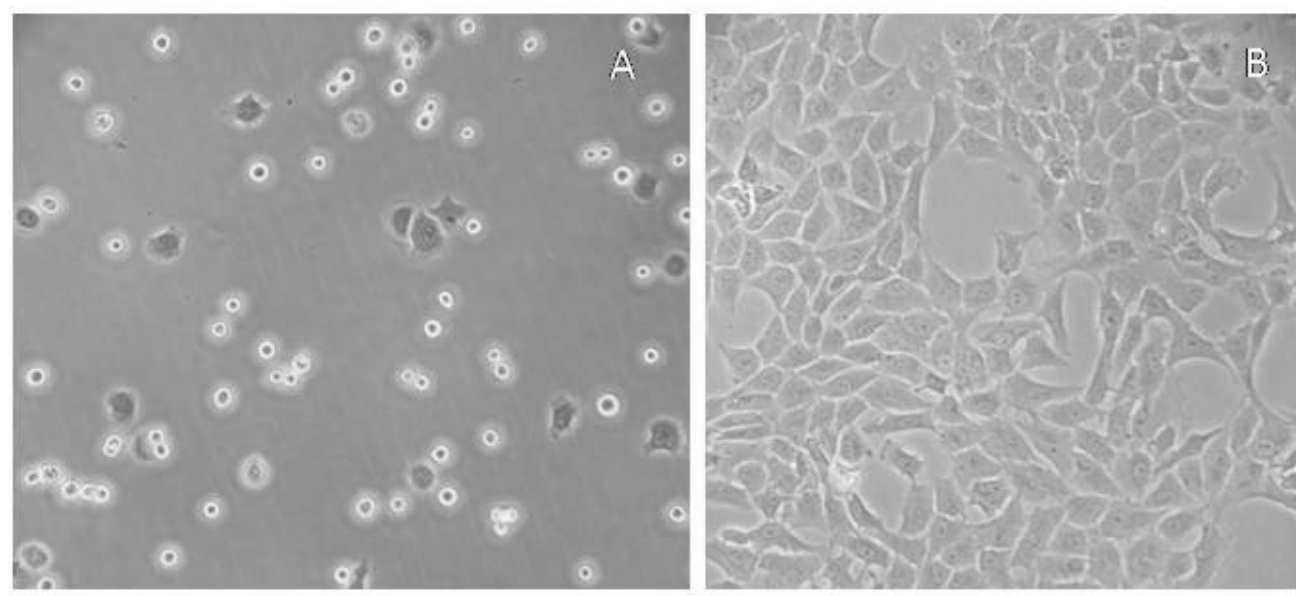

Figure 1. Primary culture of rabbit chondrocytes. (A) Appearance of chondrocytes one hour after enzymatic digestion showing cellular adhesion. (B) Chondrocytes with $75 \%$ confluence showing spreading and cellular adhesion on the third day of culture (Phase contrast, 100X).

Under the contrast phase microscope, high mitosis rate was found in the fresh chondrocytes, with fibroblastic morphology, which reached $75 \%$ confluence in three days. After 45 days of culture, the cells maintained the same characteristics and extracellular matrix was observed. Nevertheless, after 60 days, mitosis rate had decreased and the matrix was scarce.

The thawed chondrocytes showed a slow confluence rate with a mean of $50 \%$ three days after thawing. A $75 \%$ confluence rate was 
reached only after six days of culture in all samples. The presence of matrix and number of mitoses were reduced in all thawed samples after 35 days of culture.

The fresh chondrocytes showed high viability, always above 1.1 (90\%), immediately after enzymatic digestion and 15 days of culture. However, after 60 days of culture, all fresh chondrocyte samples showed a reduced viability, with a mean of 0.93 (80.4\%) (Fig. 2). The thawed chondrocytes showed low viability immediately after thawing, 0.15 (15.2\%) on average. After 15 days of culture, these chondrocytes showed viability above 1.1 (90\%) with a sharp reduction at 60 days, 0.73 (66.9\%) on average (Fig. 3).

Culture time and thawing reduced the number of cells in culture $(\mathrm{P}<0.001)$. At 15 days of culture, an increase in the number of fresh chondrocytes was found, but at 60 days, the values significantly decreased (Fig. 4). On the other hand, the number of thawed chondrocytes started to decrease from 15 days of culture, remaining until 60 days (Fig. 5).

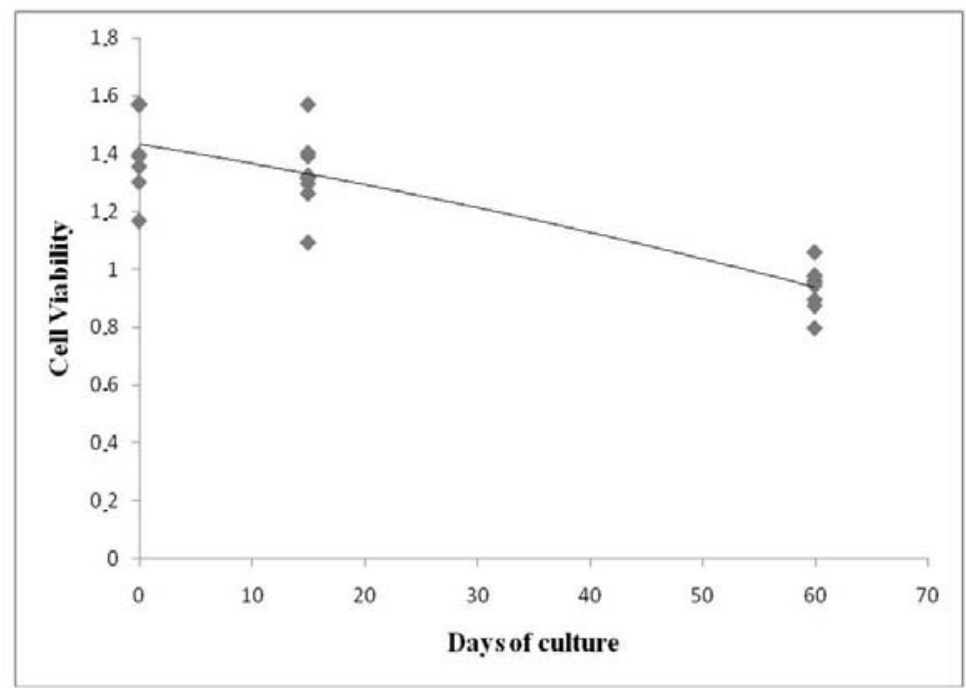

Figure 2. Cell viability of rabbit chondrocytes after enzymatic digestion (0) and after 15 and 60 days of culture. The percentage data were transformed by arcsine.

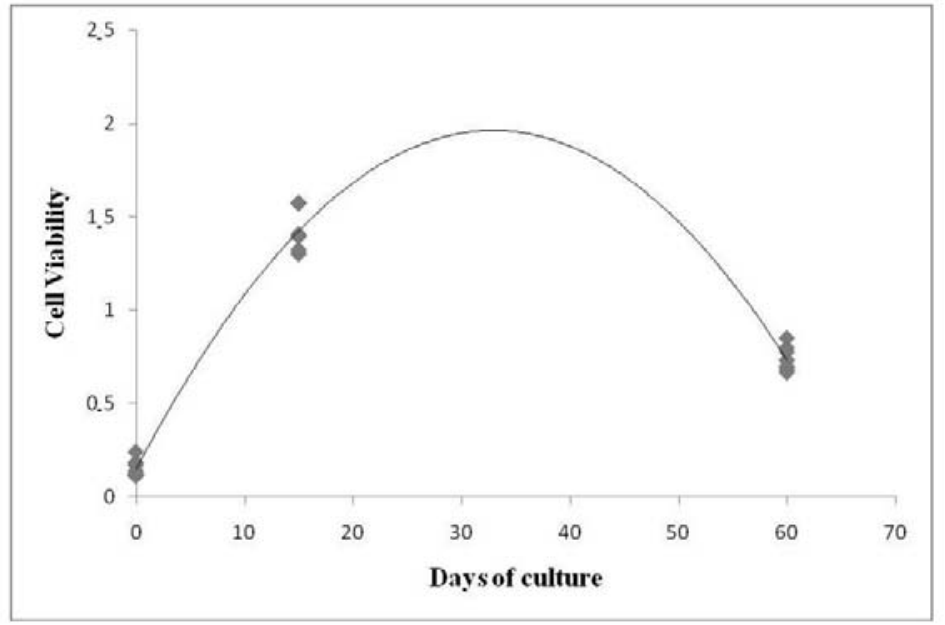

Figure 3. Cell viability of rabbit chondrocytes immediately after thawing (0) and after 15 and 60 days of culture. The percentage data were transformed by arcsine. 


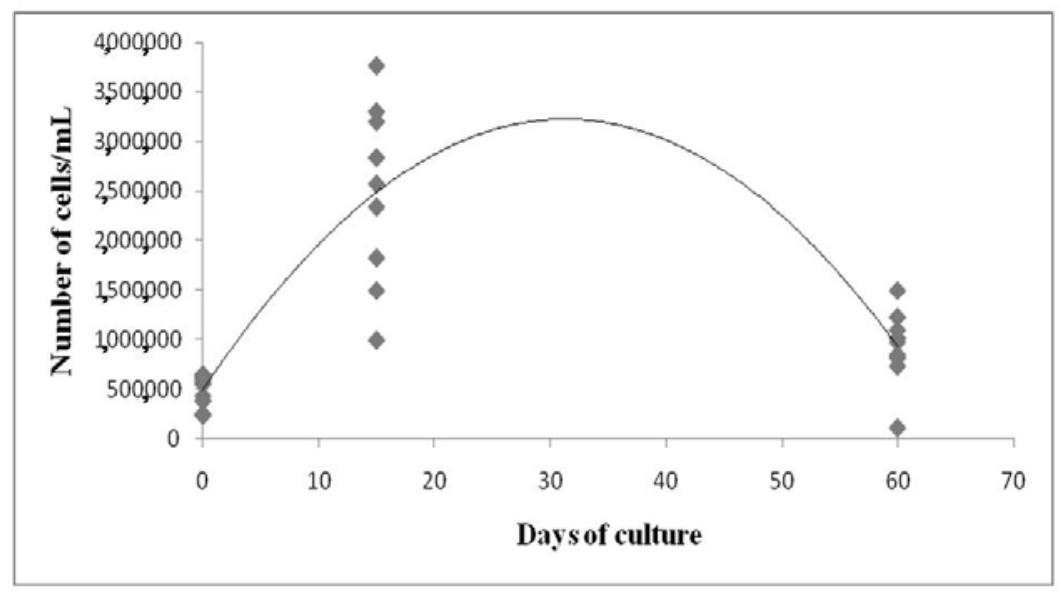

Figure 4. Number of rabbit chondrocytes/mL after enzymatic digestion (0) and after 15 and 60 days of culture.

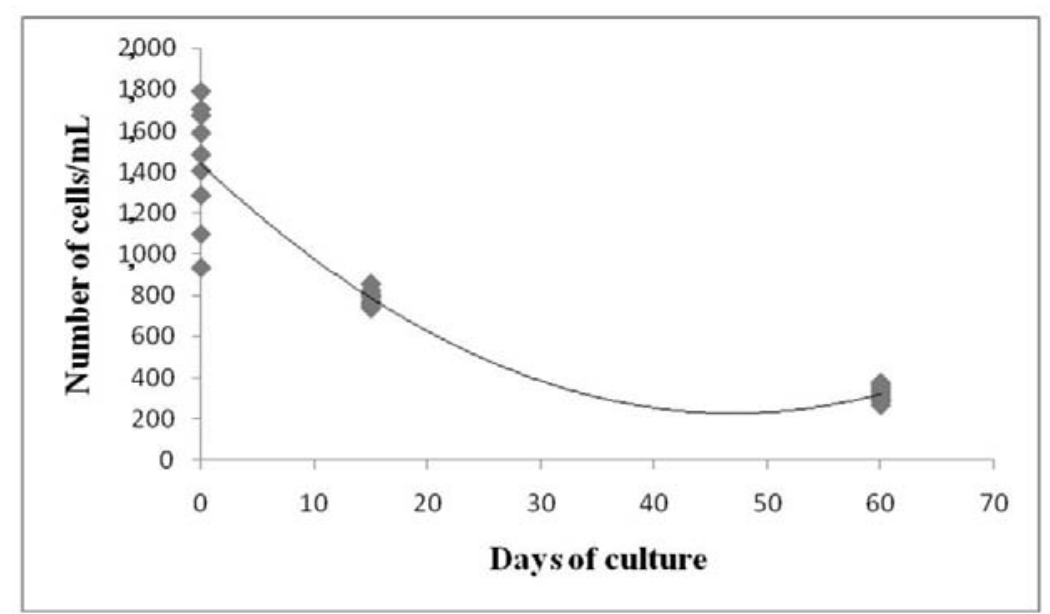

Figure 5. Number of rabbit chondrocytes/mL immediately after thawing (0) and after 15 and 60 days of culture. The absolute values were transformed by square root.

In the fresh chondrocyte samples after 15 days of culture, increase in cellular density and intense presence of matrix were observed. Nevertheless, after 60 days, decrease in cellular multiplication was observed and the matrix became sparse (Fig. 6 A e B). After 15 days of culture, the thawed chondrocytes maintained high cellular density but matrix production had reduced. After 60 days of culture, the matrix became absent and the presence of a large number of apoptotic chondrocytes was observed (Fig. 6 C and D).
In the fresh chondrocytes, positive labeling of proteoglycans was intense, characterizing the presence of a matrix rich in proteoglycans. On the other hand, the thawed chondrocytes showed decreased matrix production with a weak labeling of proteoglycans (Fig. 7). With the fresh chondrocytes, the immunostaining by indirect immunofluorescence revealed an intense and brilliant fluorescence indicating high expression of type II collagen. In the thawed cells, fluorescence was less intense, indicating a reduced expression of Type II collagen (Fig. 8). 

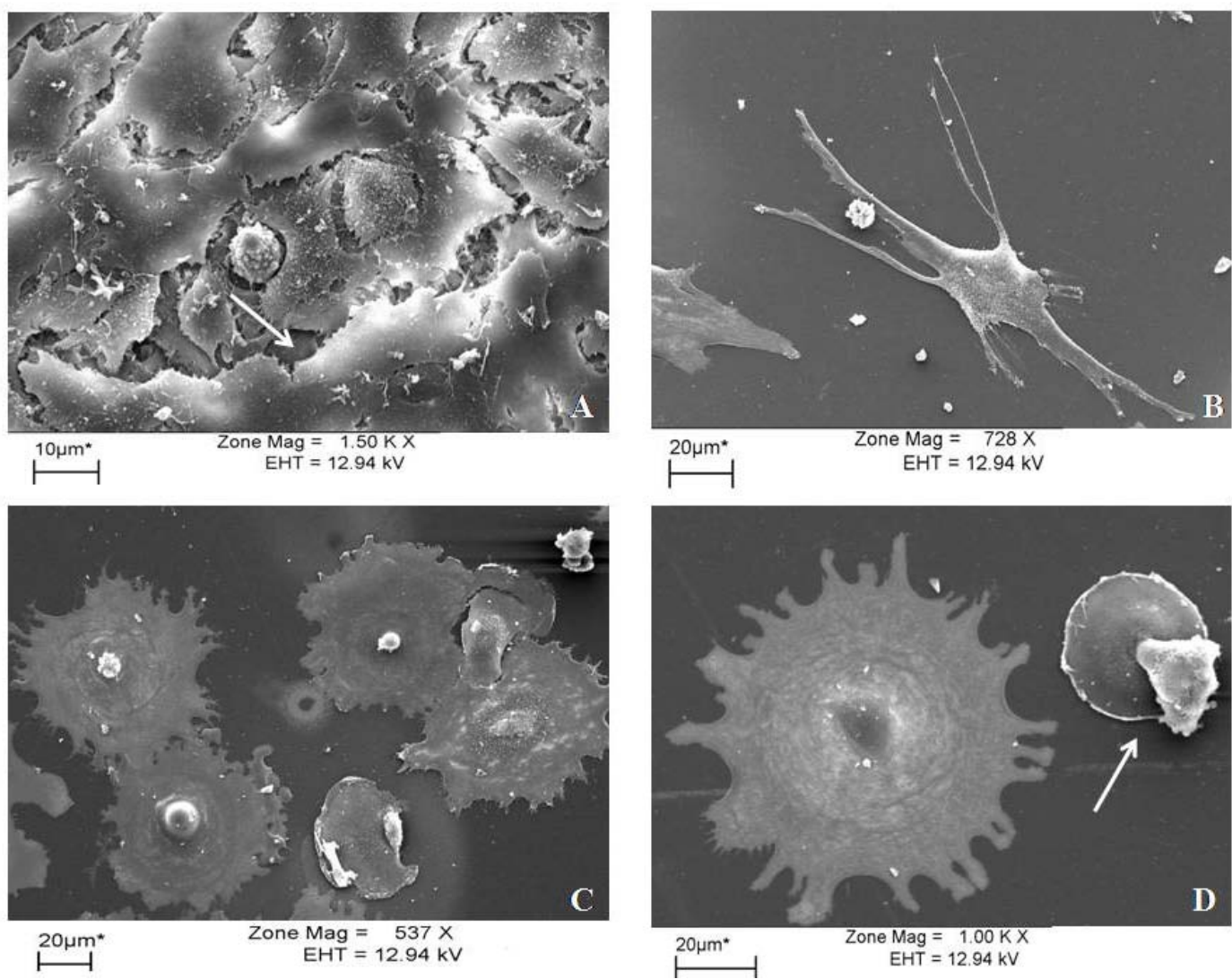

Figure 6. Photomicrographs of fresh [A (15 days) and B (60 days)] and thawed [C (15 days) and D (60 days)] chondrocytes observed under scanning electron microscope. (A) High cell density with intense presence of matrix (arrow). (B) Low cell density and matrix abscence. (C) Maintenance of cell density but less matrix is observed. (D) Presence of apoptotic chondrocytes (arrow), low cell density and lack of matrix.
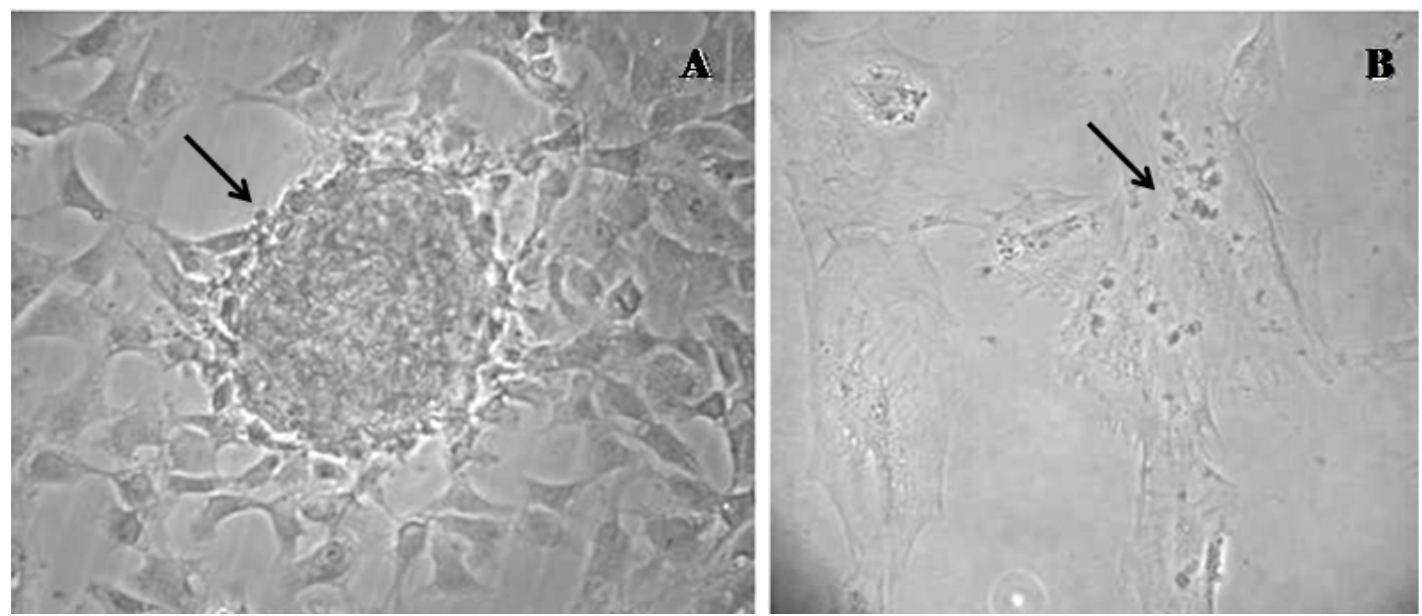

Figure 7. Labeling of rabbit chondrocytes with Alcian Blue after 15 days of culture. (A) Culture of fresh chondrocytes with presence of proteoglycans strongly marked by Alcian Blue. (B) Culture of thawed chondrocytes with little matrix and weak labeling of proteoglycans (phase contrast, 100X). 

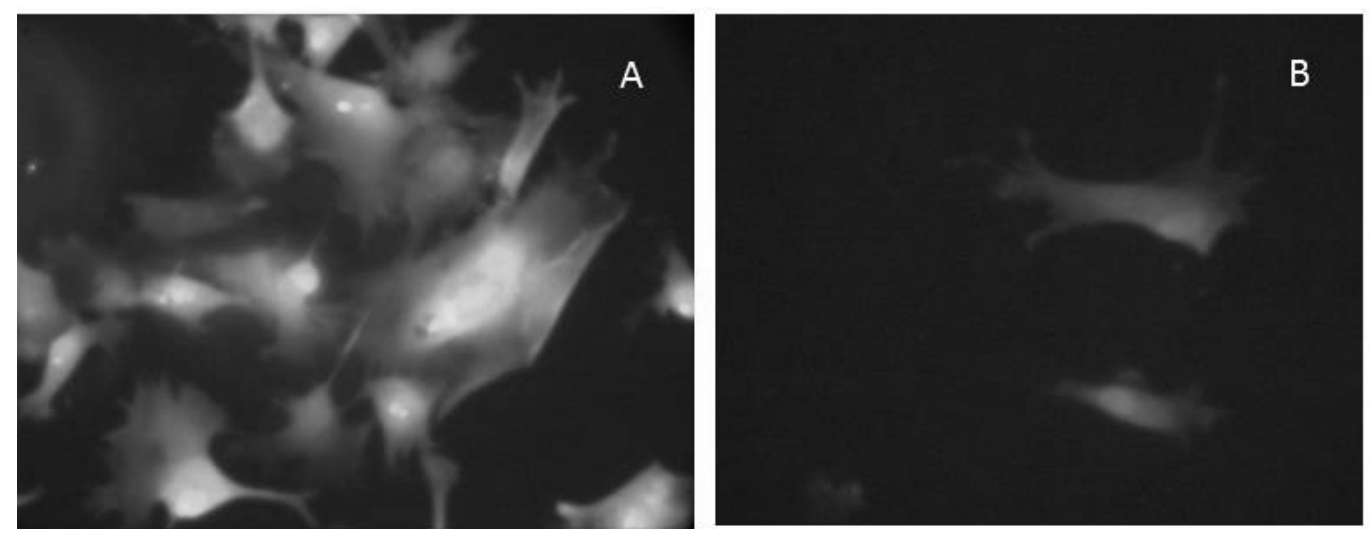

Figure 8. Indirect immunofluorescent reaction of fresh and thawed rabbit chondrocytes after 15 days of culture. (A) Fresh chondrocyte culture with intense immunostaining of Type II collagen and high cell density. (B) Thawed chondrocyte culture with discrete immunostaining of Type II collagen and low cell density (400X).

\section{DISCUSSION}

The chondrocytes which grow in monolayers rapidly lose their phenotypic characteristics and their multiplication decrease (Takahashi et al., 2003; Waldman et al., 2003; Bittencourt et al., 2009), as shown in this study after 60 days of culture, when the production of extracellular matrix and mitotic rate decreased extremely. This observation is supported by the lack of mechanical forces in vitro, which under physiological conditions are essential to stimulate matrix synthesis (Waldman et al., 2003), as well as an intense loss in the telomeres after each cellular division which consequently reduced mitotic rate (Martin and Buckwalter, 2003).

Immediately after thawing, under SEM, the cultures showed low viability and an expressive reduction of mitosis, due to death by apoptosis. According to Takahashi et al. (2003), the culture of human chondrocytes in a culture medium supplemented with FBS shows an increase in apoptosis. This may explain what was observed in the thawed cells in this study, although the freezing method cannot be excluded as a cause. The same authors stated that the substitution of a heterologous by an autologous serum at the same concentration reduced the occurrence of apoptosis by mechanisms which are not yet clear.

DMSO is a cryoprotector widely used for cell preservation during freezing and, in the present study, 5\% DMEM was used. Almqvist et al. (2001) used the same concentration for freezing human chondrocytes for 24 hours and did not observe alterations in cellular viability or matrix production. Nevertheless, in this study, freezing time was six months, which may have caused the low viability immediately after thawing all samples. The number of subcultures and culture age at the time of freezing, when the chondrocytes were more dedifferentiated, may also have influenced cell viability, suggesting that when the chondrocytic phenotype is lost it is not quickly re-expressed (Lee et al., 2003).

The loss of phenotypic stability of chondrocytes cultivated in monolayers may be associated with some culture conditions, mainly the increase in culture age, low cellular density during subculture, and number of subcultures. However, the results of the analysis of proteoglycans and type II collagen indicate that the chondrocytes remain phenotypically stable in the primary culture for two weeks, when greater matrix synthesis was observed. This finding was the opposite of what was observed at 60 days when a loss of phenotypic characteristics occurred, shown by loss of matrix. These data are in agreement with those by Lee et al. (2003), who compared cattle articular chondrocytes cultures in monolayers and in alginate submitted to subcultures every seven days. These authors showed that the reduction of proteoglycan synthesis occurred after two to four subcultures in the cultures in monolayer. Brodkin et al. (2004) found that the synthesis of type II collagen decreased over time and after successive divisions when the chondrocytes grew in monolayers. 
In the thawed chondrocytes cultures, the loss of phenotypic stability was more pronounced, which was shown by the low labeling of the proteoglycans and weak immunostaining of Type II collagen. This confirmed that the freezing procedure influenced the irreversibility of dedifferentiation of the chondrocytes, possibly due to lethal effects that occurred during freezing, when the cells underwent intermediate temperatures until frozen in liquid nitrogen. Furthermore, the dedifferentiated chondrocytes cultivated in monolayer possibly allowed the production of type I collagen and other fibroblastic matrix compounds, which was not observed in tridimensional cultures as described by Bittencourt et al. (2009).

\section{CONCLUSIONS}

Under the used freezing conditions, important loss of chondrocyte viability occurred. For future in vivo studies of heterologous implant, this result suggests that a high number of cells should be implanted in the host site in order to achieve an adequate number of viable cells. Furthermore, the chondrocytes should be implanted after two weeks of culture, when the highest viability rate is found. Other studies using substrates which sustained the chondrocytic phenotype and different concentrations of DMSO should be carried out to enable the establishment of chondrocyte banks, which will be able to preserve these cells for a long time.

\section{ACKNOWLEDGMENTS}

The present study was supported by CNPq (Brazilian Council of Research and Development) and FAPEMIG (Minas Gerais Research Support Foundation). The authors wish to thank Dr. Elisiane Pereira from Tecnogene Laboratorie for installations availability and Dr Cláudia Vanetti from the Microscopy and Microanalysis Nucleus at the Federal University of Viçosa - MG, Brazil for the Electron Microscopy Analysis.

\section{REFERENCES}

ALMQVIST, K.F.; WANG, L.; BRODDLEZ, C. et al. Biological freezing of human articular chondrocytes. Osteoarthritis Cart., v.9, p.341350, 2001.
BITTENCOURT, R.A.C.; PEREIRA, H.R.; FELISBINO, S.L. et al. Cultura de condrócitos em arcabouço tridimensional: hidrogel de alginato. Acta Orthop. Bras., v.17, p.242-246, 2009.

BRODKIN, K.R.; GARCÍA, A.J.; LEVENSTON, M.E. Chondrocyte phenotypes on different extracellular matrix monolayers. Biomaterials, v.25, p.5929-5938, 2004.

DENONCOURT, P.M.; PATEL, D.; DIMAKOPOULOS, P. Treatment of osteochondrosis dissecans of the knee by arthroscopic curettage, follow up study. Orthop. Rev., v.15, p.652-657, 1986.

FRESHNEY, R.I. (Ed). Culture of animal cells. 5.ed. New Jersey: Wiley-Liss, 2005. 642p.

HENROTIN, Y.; SANCHES, C.; BALLIGAND, M. Pharmaceutical and nutraceutical management of canine osteoarthritis: present and future perspectives. Vet. J., v.170, p.113-123, 2005.

HIDAKA, C.; GOODRICH, L.R.; CHEN, C.T. et al. Acceleration of cartilage repair by genetically modified chondrocytes over expressing bone morphogenetic protein-7. J. Orthop. Res., v.21, p.573-583, 2003.

HUNTLEY, J.S.; BUSH, P.G.; McBIRNIE, J.M. et al. Chondrocyte death associated with human femoral osteochondral harvest as performed for mosaycplasty. J. Bone Jt. Surg., v.87-A, p.351360, 2005.

JONES, D.G.; PETERSON, L. Autologous chondrocyte implantation. J. Bone Jt. Surg., v.88-A, p.2501-2520, 2006.

LEE, D.A.; REISLER, T.; BADER, D.L. Expansion of chondrocytes for tissue engineering in alginate beads enhances chondrocytic phenotype compared to conventional monolayer techniques. Acta Orthop. Scand., v.74, p.6-15, 2003.

LOMBELLO, C.; REIS Jr., G.M.; COHEN, M. Study on human chondrocyte culture viability for autologous transplantation in clinical application. Einstein, v.1, p.84-88, 2003.

MARTIN, J.A.; BUCKWALTER, J.A. The role of chondrocyte senescence in the pathogenesis of osteoarthritis and in limiting cartilage repair. $J$. Bone Jt. Surg., v.85-A, p.106-110, 2003. 
PETERSON, L.; MINAS, T.; BRITTBERG, M. et al. Treatment of osteochondritis dissecans of the knee with autologous chondrocyte transplantation. J. Bone Jt. Surg., v.85-A, p.1724, 2003.

PRUKSAKORN, D.; KHAMWAEN, N.; POTHACHAROEN, P. et al. Chondrogenic properties of primary human chondrocytes culture in hyaluronic acid treated gelatin scaffold. J. Med. Assoc. Thai., v.92, p.483-490, 2009.

SOUSA, T.D.; DEL CARLO, R.J.; VILORIA, M.I.V. Electrotherapy on the healing process in the articular surface of rabbits. Cienc. Rural, v.31, p.819-824, 2001.

STEVENSON, S. The immune response to osteochondral allografts in dogs. J. Bone Jt. Surg., v.69-A, p.573-582, 1987.

TAKAHASHI, T.; YAMAMOTO, H.; OGAWA, Y. et al. Role of apoptosis inhibition in various chondrocyte culture systems. Int. J. Mol. Med., v.11, p.299-303, 2003.

WALDMAN, S.D.; SPITERI, C.G.; GRYNPAS, M.D. et al. Effect of biomechanical conditioning on cartilaginous tissue in vitro. J. Bone Jt. Surg., v.85-A, p.101-105, 2003. 